\title{
A Local Exhibit
}

REV. FRANKLIN D. ELMER

Pastor First Baptist Church, Winsted, Connecticut

Advances in Bible school method, material and result have been so rapid during the past few years that even those in the swing of it cannot keep up. And the pity is that many, perhaps the majority of schools, are not yet awakened to the more abundant life, the new demands and opportunities of the modern Sunday school. How shall we rouse them? Here are schools pioneering far ahead! Here are others sleeping in the rear! How shall we bring back the old elbow touch? It will never come again through uniformity of lesson system. It may come in unity of spirit. Indeed, it is coming, sooner than we have hoped. The writer recently witnessed an experiment which suggests a key. Thirty churches were gathered in an associational meeting. One of the sessions was devoted to education. This session was opened with demonstration in modern method, manual work in sand, pulp, pictures and book making, Bible declamations and honor system. The session was closed with a stirring inspirational address, and the background of the whole was a Bible school exhibit of several thousand pieces, presenting graphically concrete ideas in equipment and result, progress and history of the Sunday school. "I have done it, and it is good; you can do it; this is the way, come on '" This call of personal example is the opportunity of the exhibit; it complements the address and supplements the convention.

The exhibit of the Winchester Guild, which was created originally for a community, had its source in the deposit made by one school during five years of progressive work. Examination. papers, books made by individuals or classes, quarterlies written up, maps in pulp or pencil, the honor system, certificates, a school seal and flag, such material began to accumulate and to suggest classification and exhibition for purposes of record of achievement. But that which was at first of interest to the few had an interest also for school neighbors, who came in friendliness to see and to test. Work from other schools was added. Publishing houses were invited to interest themselves. And from small beginnings, slowly, but with accumulative intensity of growth and expansion, this exhibit has enlarged from its community origin 
to occupy a place of distinction in a great state meeting.

Our experience would seem to suggest that any guild might with profit add such a department to its activity. 'The first object should be the collection and proper presentation of the work actually accomplished in its field. As an inspiration to the scholars of the churches interested, and as a guide and help to the teachers, the results which they produce and which may be thus shown are of primary importance. Indeed, the exhibit would be of great value if it went no further than this. Publishing houses are beseiged with solicitations for free material and must not be expected to contribute. All inquiries however will be most courteously answered and their assistance will be found invaluable. The exhibit may be housed in some neutral room readily accessible to all, and may contain material to be used by the several schools in turn on loan from the common store. It will be seen at once how powerful would be the unifying influence of such a collection among the churches and schools represented. The commercial element is eliminated, the educational predominates. The best equipment, not the cheapest, would come to be demanded through the educated appetite, and some would experience a wholesome shock over the neglect which our Sunday schools have suffered. The benefits of such an exhibit would overflow the limits of its source and be helpful in all the work of the guild. An illuminating article on the general subject is to be found on page 216 of the volume of proceedings of the Boston convention.

\section{Exhibit Library}

Although the special reference library at the executive office now has nearly 400 volumes on religious education, there are still a number of books needed to make this in any sense a complete reference library on its special subject. Amongst those for which there is the most pressing need are: James, "Varieties of Religious Experience"; Hall, "Adolescence"; Butler et al., "Principles of Religious Education"; Starbuck, "Psychology of Religion"; Adler, "Moral Instruction of Children"; James, "Talks to Teachers." These books were published before this collection was begun. Perhaps some members will be willing to present them to the library. 